\title{
Entre Normas e Práticas: Pesquisa Empírica no Direito em Diálogo com as Ciências Sociais
}

\author{
Between Norms and Practices: Legal Empirical Research in \\ Dialogue with Social Sciences
}

Michel Lobo Toledo Lima ${ }^{1}$

\section{RESUMO}

Neste Dossiê estão reunidos artigos com ênfase na pesquisa empírica, com usos de vários métodos das Ciências Sociais, qualitativos e quantitativos, inclusive mistos - tais como etnografia, trabalho de campo, observação participante, observação direta, comparação por contrastes, entrevistas formais ou informais, análise de fluxo longitudinal retrospectivo, análise de discurso e análise de documentos oficiais, inclusive com usos de softwares como NVIVO, SPSS e Microsoft Excel. Todos desenvolvem argumentação crítica e reflexiva sobre o sistema jurídico brasileiro atual, explicitando suas contradições, seus dilemas, suas especificidades e seus "sentidos de justiça", sobretudo ao se contrastar as leis, as doutrinas, e os tipos ideais do "dever ser" jurídico perante suas práticas judiciais e judiciárias. Esse dossiê também reflete uma articulação entre universidades, públicas e privadas, de vários Estados e regiões do país Pontifícia Universidade Católica do Rio Grande do Sul, Universidade Católica de Petrópolis, Universidade Federal Fluminense, Universidade Federal de Minas Gerais, Universidade Federal Rural do Rio de Janeiro, Universidade de Brasília, Universidade do Estado do Mato Grosso, Universidade Estácio de Sá, Universidade Presbiteriana Mackenzie de São Paulo, Universidade de São Paulo, Universidade Santa Úrsula e Universidade Veiga de Almeida - e entre redes de pesquisadores que se desenvolvem no Brasil, algumas delas instituídas e articuladas com pesquisas sobre o campo do Direito. Do mesmo modo, outro produto no qual essa publicação se enquadra é a divulgação de atividades relacionadas ao projeto de pesquisa de pós-doutorado FAPERJ nota 10, intitulado "Entre Normas e Práticas: Paradoxos na Administração Institucional de Casos Penais no Modelo Jurídico-Policial Brasileiro em Perspectiva Comparada". Tal projeto, ainda em andamento, está sendo executado no Núcleo de Pesquisa em Processos Institucionais Administração de Conflitos do Programa de PósGraduação em Direito da Universidade Veiga de Almeida, ambos vinculados ao Instituto de Estudos Comparados em Administração de Conflitos. Longe de uma única representatividade institucional, a mencionada pesquisa de pós-doutorado tem também como objetivo, desde o seu início, promover o trabalho de interlocução entre as ciências sociais e as ciências sociais aplicadas, especialmente entre as ciências sociais e o direito, com foco em pesquisas que não são "sobre" o Direito, mas realizadas "com" o Direito, notadamente aqui representadas por seus operadores e pesquisadores, enquanto autores dos artigos desse dossiê. É um esforço, entre

\footnotetext{
1 Doutor e mestre em Sociologia pelo Instituto de Estudos Sociais e Políticos da Universidade do Estado do Rio de Janeiro (IESP/UERJ). Pós-graduado em Políticas Públicas de Justiça Criminal e Segurança Pública pela Universidade Federal Fluminense (UFF). Graduado em Direito pela Pontifícia Universidade Católica do Rio de Janeiro (PUC-Rio). Professor visitante do Programa de Pós-graduação em Direito da Universidade Veiga de Almeida (PPGD-UVA). Pesquisador de pós-doutorado FAPERJ nota 10 no PPGD-UVA. Pesquisador do Instituto de Estudos Comparados Em Administração Institucional de Conflitos (INCT/InEAC - UFF). E-mail: michell_lobo@hotmail.com
} 
outros, de contribuição para a construção de uma tradição de diálogo interinstitucional e interdisciplinar de pesquisas com o Direito, em que a Revista Juris Poiesis, vinculada ao Programa de Pós-Graduação Stricto Sensu em Direito da Universidade Estácio de Sá, se insere como um espaço fundamental, consolidado e permanente, para a promoção e divulgação de tais trabalhos empíricos. Para esta publicação foram recebidas e aprovadas as colaborações de 27 autores, representadas em 16 textos.

\title{
PALAVRAS-CHAVE
}

Pesquisa empírica; antropologia do direito; sociologia do direito, interdisciplinariedade; interinstitucionalidade.

\begin{abstract}
This Dossier brings together articles with an emphasis on empirical research, using various methods from the Social Sciences, qualitative and quantitative, including mixed methods - such as ethnography, fieldwork, participant observation, direct observation, contrastive comparison, formal or informal interviews, retrospective longitudinal flow analysis, discourse analysis and analysis of official documents, including with software such as NVIVO, SPSS and Microsoft Excel. The articles also bring critical and reflexive argumentation about the current Brazilian legal system, making explicit its contradictions, its dilemmas, its specificities and its "senses of justice", especially when contrasting laws, doctrines, and the ideal types of legal dogmatics to judicial and court practices. This dossier also articulates authors who work at several universities, public and private, from various states and regions of Brazil - Pontifícia Universidade Católica do Rio Grande do Sul, Universidade Católica de Petrópolis, Universidade Federal Fluminense, Universidade Federal de Minas Gerais, Universidade Federal Rural do Rio de Janeiro, Universidade de Brasília, Universidade do Estado do Mato Grosso, Universidade Estácio de Sá, Universidade Presbiteriana Mackenzie de São Paulo, Universidade de São Paulo, Universidade Santa Úrsula and Universidade Veiga de Almeida who are representative of researchers' networks on the field of Law in Brazil, some of them well established and consolidated. This publication also shed light upon activities related to the post-doctoral research project FAPERJ nota 10, entitled "Between Norms and Practices: Paradoxes in the Institutional Administration of Criminal Cases in the Brazilian Legal-Police Model in Comparative Perspective". This project, still in progress, is being executed in the Núcleo de Pesquisa em Administração Institucional de Conflitos of the Graduate Program in Law at the Universidade Veiga de Almeida, both linked to the Instituto de Estudos Comparados em Administração de Conflitos. Far from a single institutional representation, the mentioned post-doctoral research has also aimed, since its beginning, at promoting the dialogue between social sciences and applied social sciences, especially between social sciences and Law, focusing on research that is not only "about" Law, but also carried out "with" Law, notably represented here by its operators and researchers, as authors of the articles of this dossier. It is an effort, among others, to contribute to the construction of a tradition of inter-institutional and interdisciplinary dialogue of research with Law, in which the Juris Poiesis Journal, linked to the Graduate Program in Law at Universidade Estácio de Sá, is a fundamental, consolidated and permanent space for the promotion and dissemination of such empirical work. For this publication, the contributions of 27 authors were received and approved, represented in 16 texts.
\end{abstract}

\section{KEYWORDS}


Empirical research; anthropology of law; sociology of law, interdisciplinary research on Law; interinstitutional research on Law;

\section{ESTRANHAMENTOS E INQUIETUDES: ENTRE DOUTRINAS, TEORIA E PRÁTICAS NO DIREITO}

Não é incomum assistirmos notícias jornalísticas periódicas sobre atos e decisões do nosso sistema judicial que frequentemente apontam seletividades tanto na concessão de privilégios, embaraçados enquanto direitos, quanto na distribuição de deveres e responsabilidades; mas que também são comumente apresentados como desvios extraordinários ou pontuais por essas próprias instituições. Tal ausência de estranhamento desses fatos demonstra o quanto é internalizada a nossa lógica da produção jurídica da desigualdade ${ }^{2}$, não apenas no âmbito interno das instituições judiciais, mas também no campo jurídico em geral cartórios, polícias judiciárias, campos extrajudiciais de administração de conflitos, instâncias superiores e inferiores do Judiciário, etc. - e no campo acadêmico em que o saber e o fazer jurídico se reproduzem, especialmente nas Faculdades de Direito. Se no Brasil, como já apontou Roberto DaMatta (1979), as pessoas, nas relações sociais cotidianas, não se veem como iguais, a justiça ${ }^{3}$ também não as considera assim. E o papel pedagógico que o judiciário exerce em qualquer sociedade, aqui se caracteriza pelo reforço dessa desigualdade. O contexto da Pandemia do COVID-19 no Brasil é uma ilustração explícita e atual da lógica que orienta a corporação judicial $^{4}$, demonstrando que associações e instituições judiciárias adquirem

\footnotetext{
2 Vale relembrar uma já tradicional percepção da (des)igualdade jurídica expressa na Oração aos Moços, de Ruy Barbosa, dispondo que "A regra da igualdade não consiste senão em quinhoar desigualmente aos desiguais, na medida em que se desigualam. Nesta desigualdade social, proporcionada à desigualdade natural, é que se acha a verdadeira lei da igualdade" (BARBOSA, 1997, p. 26).

3 No nosso discurso jurídico, e até no senso comum, Judiciário e Justiça são usados como sinônimos, como, por exemplo: "ir à Justiça", "ser da Justiça", "trabalhar na Justiça" e "receber Justiça".

4 Algumas notícias como ilustração: - Covid-19: Juízes 'correm risco' ao manusear processos em papel, diz associação sobre polêmica de vacina. Disponível em: https://www.bbc.com/portuguese/brasil-56376396>. Acesso em 01/abr./2021.

- Além de ofício à Fiocruz, STF pediu ao Butantan reserva da Coronavac para os seus funcionários. Disponível em: <https://www1.folha.uol.com.br/equilibrioesaude/2020/12/alem-de-oficio-a-fiocruz-stf-pediu-ao-butantanreserva-da-coronavac-para-7000-servidores.shtml>. Acesso em 01/abr./2021.

- Depois de Supremo, Tribunal Superior do Trabalho pede vacina. Disponível em: $<$ https://www.cnnbrasil.com.br/nacional/2020/12/23/depois-de-supremo-tribunal-superior-do-trabalho-pedeprioridade-para-vacina>. Acesso em 01/abr./2021.
} 
características de corporações, particularizando a interpretação das regras e aplicando-as como se levasse em consideração o que considera como interesse público, em que a noção de público está vinculada a uma perspectiva estatal que, travestida de um discurso de representativa da soma de interesses individuais, na verdade reflete interesses particulares de corporações do Estado (LIMA, M. 2017, p. 148).

Tais fatos também remetem para a reflexão sobre a maneira como se constroem e se instituem os elementos da dogmática jurídica, produzida no contexto do Direito - tanto na academia, quanto nos Tribunais - que se refere ao "dever ser" e que se reflete nas formas de aplicação e interpretação da lei no Brasil, contrastando-as eventualmente com sua expressão equivalente em outras sensibilidades e sistemas jurídicos ocidentais contemporâneos (CARDOSO DE OLIVEIRA, 2011. DUARTE; IORIO FILHO, 2019. FERREIRA, 2004. GARAU, 2020. GERALDO, 2019. LIMA, M., 2020. LIMA, R., 2010. PAES, 2013. POLICARPO, 2016. SCHRITZMEYER, 2018. SIMIÃO, 2014).

A proposta desse dossiê foi reunir trabalhos que, por meio da pesquisa empírica, fossem capazes de estranhar e relativizar a forma engessada e idealizada da verdade produzida na dogmática jurídica e o abismo que existe entre ela e a prática judiciária e jurídica, no Brasil. Tais trabalhos também se voltaram para detectar os processos de produção e reprodução da prática jurídica, em um locus em que são socializados profissionalmente os operadores do direito, assim como para perceber a natureza dos conflitos levados pela sociedade às agências destinadas a administrar tais conflitos. Releva-se também as particularidades do tratamento jurídico - judicial ou extra-judicial - concedido a casos semelhantes.

Somado a isso, há a questão dificuldade de acesso à justiça por boa da parte da população. No entanto, independentemente desta configuração, outros fatores pouco privilegiados até então, podem interferir na decisão de buscar ou não a demanda pela justiça. A empiria, portanto, permite constatar a importância de interferências no trato de conflitos pelo judiciário que ainda permanecem opacas ao olhar do Direito, uma vez que o campo jurídico brasileiro ainda não produziu teorias explicativas sobre suas práticas nem métodos de pesquisas próprios do seu campo. Portanto, é corriqueiro vermos a doutrina jurídica brasileira não só atribuindo sua tida autonomia epistemológica em relação às demais áreas do conhecimento,

\footnotetext{
- Justiça e MP criam "penduricalhos" em meio à pandemia. Disponível em: <https://politica.estadao.com.br/noticias/geral,justica-e-mp-criam-penduricalhos-em-meio-apandemia,70003297383>. Acesso em 01/abr./2021.
} 
negando uma promissora interdisciplinaridade, como também se autoproclamando como uma ciência - e, portanto, como um campo do conhecimento - capaz de produzir outras ciências, ou seja, o campo do direito se diz capaz de (re)produzir conteúdos de outros campos acadêmicos, mesmo que não haja diálogos com eles, ou que não use seus métodos de pesquisa ou suas teorias explicativas. De tal modo, é comum que se tenha, no campo do Direito, uma antropologia jurídica sem etnografia, uma história do direito sem historiografia, uma economia do direito sem econometria e uma sociologia jurídica sem um problema sociológico (GERALDO; FONTAINHA, 2015, p. 10).

Tais questões podem decorrer da própria prática jurídica, também ensinada implicitamente na sua academia, de determinadas interpretações concedidas às leis em casos específicos ou da descaracterização de conflitos não previstos na legislação, que deixa sem tratamento adequado situações que prosseguem abrigando conflitos potenciais. Se isto ocorre, como se admite aqui, a função judicante não estaria cumprindo o papel a ela oficialmente atribuído de interferir positiva, pedagógica e explicitamente na manutenção da estabilidade e segurança social.

Quando se fala em acesso à justiça, há que perguntar, acesso a “qual” justiça, no sentido de que a distância entre as representações do mundo e do próprio direito tem se constituído no Brasil como uma maneira de afirmar um saber que é exclusivo das autoridades judiciárias. Sabidamente, em várias pesquisas, nosso direito - e, portanto, as instituições que o representam e que dispensam justiça à sociedade - se define como uma região de saber complexo e esotérico a que apenas alguns poucos iluminados teriam acesso. As expectativas do cidadão comum e, por conseguinte a satisfação da população com a justiça que lhe é dispensada, não se encontra entre as prioridades do saber jurídico.

Por outro lado, pesquisas sobre as práticas burocráticas em nosso sistema judicial em perspectiva comprada por contrastes, têm estado sob foco no Brasil desde a década de 1980, embora em passos lentos. Boa parte desses trabalhos empíricos demonstra como tais práticas se (re)produzem de maneira informal e quase invisível, à margem da lei e das doutrinas jurídicas, mas compartilhando valores corporativos que orientam práticas institucionais locais (AMORIM, 2017. AZEVEDO, 2001. BAPTISTA, 2013. BERNARDINA, 2019. BRITO, 2017. CARDOSO DE OLIVEIRA, 2011. CORRÊA, 2012. DUARTE, IORIO FILHO, 2015. FERREIRA, 2005/ FIGUEIRA, 2008. FILGUEIRAS, 2015. FILPO, 2016. GERALDO, 2019. 
LIMA, M., 2017. LIMA, R., 2019. MENDES, 2012. MOUZINHO, 2019. NUÑEZ, 2018. POLICARPO, 2020. RIBEIRO, 1995. SETA, 2015. VARGAS, 2000. VIDAL, 2013).

Partindo dessas questões e reflexões surgiu a motivação da organização e produção do presente dossiê, a ser publicado em um periódico do Direito que prioriza trabalhos empíricos e em diálogo com os métodos das Ciências Sociais.

\section{A CONSTRUÇÃo de UMA TRAdiÇÃo DE PESQUiSAS COM O DIREITO NO BRASIL: $O$ PAPEL DA INTERDISCIPLINARIDADE $E$ DA INTERINSTITUCIONALIDADE}

Partindo do contexto já mencionado, aqui estão reunidos artigos com ênfase na pesquisa empírica, com usos de vários métodos das Ciências Sociais, qualitativos e quantitativos, inclusive mistos - tais como etnografia, trabalho de campo, observação participante, observação direta, comparação por contrastes, entrevistas formais ou informais, análise de fluxo longitudinal retrospectivo, análise de discurso e análise de documentos oficiais, inclusive com usos de softwares como NVIVO ${ }^{5}$, SPSS $^{6}$ e Microsoft Excel ${ }^{7}$. Os artigos também desenvolvem argumentação crítica e reflexiva sobre o sistema jurídico brasileiro atual, enfatizando suas contradições, seus dilemas, suas especificidades e sua sensibilidade jurídica (GEERTZ, 2002), sobretudo quando se contrastam as doutrinas, leis e tipos ideais do "dever ser" jurídico com suas práticas judiciais e judiciárias.

Além disso, esse dossiê se engaja enquanto um produto de articulação entre autores pertencentes a uma considerável diversidade de universidades, públicas e privadas, de vários Estados e regiões do país - Pontifícia Universidade Católica do Rio Grande do Sul (PUC-RS), Universidade Católica de Petrópolis (UCP), Universidade Federal Fluminense (UFF), Universidade Federal de Minas Gerais (UFMG), Universidade Federal Rural do Rio de Janeiro (UFRRJ), Universidade de Brasília (UnB), Universidade do Estado do Mato Grosso

5 Sigla em inglês que define um conjunto de programas de computador voltados para a construção e organização de dados qualitativos - computer aided qualitative data analyses software - tais como entrevistas, respostas abertas de pesquisa, artigos e mídias sociais.

6 Statistical Package for the Social Sciences.

7 Programa que permite criar, exibir e editar planilhas com tabelas, gráficos e modelos matemáticos. 
(UNEMAT), Universidade Estácio de Sá (UNESA), Universidade Presbiteriana Mackenzie de São Paulo (UPM-SP), Universidade de São Paulo (USP), Universidade Santa Úrsula (USU) e Universidade Veiga de Almeida (UVA). Representa também uma expressão do trabalho em rede de pesquisadores que se desenvolve no Brasil, algumas delas instituídas e articuladas com pesquisas sobre o campo do Direito, como é o caso do Centro de Estudos de Criminalidade e Segurança Pública (CRISP/UFMG); Grupo Interdisciplinar de Pesquisa sobre Administração de Conflitos (GIPAC/UCP); do Grupo de Pesquisa sobre Formas Consensuais de Administração de Conflitos em Perspectiva Empírica (FOCA/ITR-UFRRJ); do grupo de pesquisa "Mulher, Sociedade e Direitos Humanos" (MSD/UPM-SP); do Grupo de Pesquisa em Políticas Públicas de Segurança e Administração da Justiça Penal (GPESC/PUC-RS); do Laboratório de Estudos sobre Cidadania, Administração de Conflitos e Justiça (CAJU/UnB); do Laboratório de Estudos sobre Conflitos, Cidadania e Segurança Pública (LAESP/UFF); do Núcleo de Antropologia do Direito (Nadir/USP); do Núcleo de Estudos e Pesquisas sobre Sujeitos, Sociedade e Estado (NEPSSE/UFF); do Núcleo de Pesquisa em Processos Institucionais Administração de Conflitos (NUPIAC/UVA); do Núcleo de Estudos sobre Direito, Cidadania, Processo e Discurso (NEDCPD/UNESA); e do Núcleo de Sociologia do Direito (NSD/UFF); a maioria deles vinculados ao Instituto de Estudos Comparados em Administração Institucional de Conflitos (INCT-InEAC/UFF) ${ }^{8}$; e outras agremiações. A presença dessa diversidade institucional, regional e de campos do conhecimento evidencia o grande e diverso interesse acadêmico despertado e o potencial das pesquisas acerca das reflexões empíricas no e do campo do direito no Brasil.

Do mesmo modo, outro escopo desta publicação é a divulgação de atividades relacionadas ao projeto de pesquisa de pós-doutorado FAPERJ nota 10, intitulado "Entre Normas e Práticas: Paradoxos na Administração Institucional de Casos Penais no Modelo

8 O Instituto de Estudos Comparados em Administração de Conflitos (INCT-InEAC - www.ineac.uff.br), sediado na Universidade Federal Fluminense. O InEAC teve seus projetos aprovados por duas vezes, nas Chamadas No 15/2008 MCT/CNPq/FNDCT/CAPES/FAPEMIG/FAPERJ/ FAPESP e No 16/2014 INCT/MCT/CNPq/CAPES/FAPs do Programa Institutos Nacionais de Ciência e Tecnologia/CNPq, o qual visa a fortalecer a formação qualificada de quadros para o desenvolvimento de pesquisa de excelência, internacionalizar os resultados da pesquisa e transferir tais resultados para a sociedade. O InEAC, assim, constitui-se em consolidada rede nacional e internacional de aproximadamente 100 pesquisadores doutores e outros $200 \mathrm{em}$ formação, instituições de ensino, pesquisa e extensão, reunidos há 12 anos e presente em 7 estados brasileiros (RJ, RR, MG, SP, PE, BA, RS, DF) e, além do Brasil, em sete países estrangeiros, (Canadá, Argentina, França, Estados Unidos, Portugal, Suíça, Peru). Entre outros objetivos específicos, o InEAC visa, desde o seu início, promover o trabalho de interlocução, inédito no Brasil, entre as Ciências Sociais e as Ciências Sociais Aplicadas. 
Jurídico-Policial Brasileiro em Perspectiva Comparada", de Michel Lobo Toledo Lima, coordenador do presente dossiê. Tal projeto de pesquisa propõe que há uma falsa disputa no campo jurídico brasileiro que provém da utilização alternada e alternativa de diferentes lógicas que orientam as práticas judiciárias e as interpretações das previsões legais. Lógicas fundadas ora em um direito tido como tradicional, baseado num Estado interventor e tutelar, ora na invocação de um direito tido como moderno, inovador, fundado num Estado mínimo. E que embora sejam diferentes e por vezes até opostas entre si, não se anulam, mas que convivem, ora se sobrepondo uma noutra, por vezes criando modelos híbridos de "justiça", conforme os interesses muitas vezes puramente institucionais (?) acerca do caso a ser administrado, retroalimentando discursos e práticas que fazem, reiteradamente, do novo a reafirmação do velho, no sentido de travestir práticas tradicionais inquisitoriais e hierárquicas no campo do direito e da segurança pública com discursos igualitários, universais e inclusivos. Com esse movimento, pretende-se legitimar uma burocracia jurídico-policial pessoalizada, sigilosa e que antagoniza práticas, discursos jurídicos e normas universalizantes vigentes, com o fim de relativizá-las e interpretá-las particular e arbitrariamente, sem limites que não sejam aqueles internos às corporações envolvidas.

Tal projeto, ainda em andamento, está sendo executado no NUPIAC - coordenado pelos Professores Roberto Kant de Lima e Maria Stella Faria de Amorim - do Programa de PósGraduação em Direito da Universidade Veiga de Almeida (PPGD-UVA), vinculados ao INCTInEAC. Longe de uma única representatividade institucional, a mencionada pesquisa de pósdoutorado tem também, como objetivo, desde o seu início, promover o trabalho de interlocução entre as ciências sociais e as ciências sociais aplicadas, especialmente entre as ciências sociais e o direito, com foco em pesquisas que não são "sobre" o Direito, mas realizadas "com" o Direito, notadamente aqui representadas por seus operadores e pesquisadores, enquanto autores dos artigos desse dossiê. É um esforço, entre outros (AMORIM; BAPTISTA; LIMA, M.; LIMA R.; DUARTE; 2021. AMORIM; LIMA M.; LIMA, R.; 2020. LIMA, M.; LIMA, R. 2020), de contribuição para a construção de uma tradição de diálogo interinstitucional e interdisciplinar de pesquisas com o Direito, em que a Revista Juris Poiesis, vinculada ao Programa de PósGraduação Stricto Sensu em Direito da Universidade Estácio de Sá (PPGD/UNESA), se insere

9 Edital FAPERJ No 05/2019 - Programa Pós-Doutorado Nota 10. Disponível em: <http://www.faperj.br/downloads/Resultado_do_Programa_de_Pos_Doutorado_Nota_10_PDR_10_2019.pdf>. Acesso em 11/abr./2021. 
como fundamental espaço consolidado e permanente para a promoção e divulgação de tais trabalhos empíricos.

Essa cooperação é essencial para colaborar na formação de uma massa crítica no campo do Direito que dê conta da formulação de hipóteses e teorias que interpretem, na melhor tradição sociológica, os efeitos do direito quando aplicado à sociedade, superando, assim, a conhecida dicotomia do campo jurídico brasileiro entre doutrina (do dever ser) e prática jurídica, muitas vezes expressa no campo jurídico como uma inescapável contradição entre "teoria" e prática. Não há contradição possível entre doutrina e prática jurídica, pois a doutrina não se refere a práticas atualmente realizadas, mas a concepções abstratas sobre o dever ser jurídico, diante das quais as práticas sempre estarão em descompasso. Já não é o que deve acontecer entre teoria, fundada na experiência dos pesquisadores com as práticas jurídicas e o sentido que lhes empresta sua interpretação sociológica, que não admite descompasso entre teoria e prática, mas um eterno diálogo, destinado a oferecer substratos não só para o avanço do conhecimento, mas para sua eventual conversão em políticas públicas que venham contribuir para o melhor desempenho dos papeis sociais das instituições jurídicas na sociedade (LIMA, M.; LIMA, R., 2020).

\section{O CAMPO DO DIREITO BRASILEIRO E A PESQUISA EMPÍRICA: DILEMAS E CONTRIBUIÇÕES}

Diante do exposto, os trabalhos aqui reunidos são produtos de inúmeros outros empenhos institucionais. Igualmente, a seleção dos trabalhos aqui publicados ocorreu a partir de eventos acadêmicos ao longo de 2020, no âmbito da citada pesquisa de pós-doutorado, envolvendo, a saber: o Simpósio de Pesquisa Pós-Graduada 43 - Rituais judiciários, profissões jurídicas, sistema de justiça e pesquisa empírica no e/ou do direito em diálogo com a antropologia e a sociologia, do $44^{\circ}$ Encontro Anual da Associação Nacional de Ciências Sociais da Associação Nacional de Pós-Graduação e Pesquisa em Ciências Sociais (ANPOCS); o Grupo de Trabalho 25 - Administração Institucional de Conflitos no Âmbito Policial e Judicial Durante a Pandemia: rupturas e continuidades do $11^{\circ}$ Congresso Internacional De Ciências Criminais (CICCrim); do Grupo de Trabalho 01 - Reflexões sobre o Direito: teorias, saberes, 
disputas e danos do V Encontro de Pesquisas em Administração de Conflitos; a Mesa Redonda Dinâmicas Das mortes Violentas e Administração Institucional de Homicídios no VI Congresso da Associação Latino-americana de Antropologia Social (ALA); a Mesa de Conversa Perspectivas Empíricas sobre o Direito do InEAC ao Vivo; e a Mesa de Conversa Gestão de Mortos e Mortes em Tempos de Pandemia do InEAC ao Vivo.

Os autores dos artigos aqui publicados, que apresentaram trabalhos em algum(ns) dos mencionados eventos, foram convidados a publicá-los aqui desde que incorporassem as críticas construtivas apresentadas pelos coordenadores e/ou debatedores nas suas respectivas apresentações. Posteriormente, a redação final foi examinada por pareceristas pesquisadores da área das ciências humanas para confirmar sua adequação a essa publicação, sendo todos focados para uma discussão acadêmico-científica na área de estudos que envolvem a problemática do projeto aqui proposta. Para esta publicação foram recebidas e aprovadas as colaborações de 27 autores, representadas em 16 textos.

O artigo de abertura é o de Fernanda Duarte, Bárbara Gomes Lupetti Baptista e Rafael Mario Iorio Filho que descreveram e problematizaram o caso da operação Métis da polícia federal, deflagrada no bojo da operação Lava Jato e autorizada pelo juiz federal da $10^{\mathrm{a}}$ Vara Federal de Brasília, o que acarretou na prisão de quatro policiais legislativos. Tal fato, como analisaram os autores, instalou uma "crise" nas relações entre o Poder Legislativo e o Poder Judiciário, diante da declaração do Senador Renan Calheiros, então Presidente do Congresso Nacional, que se sentiu "ofendido" pelo fato do Congresso ter sido alvo de buscas e apreensões determinadas por um "juizeco" de 1ª instância, nas próprias palavras do referido Senador. O caso se desdobrou em medida judicial, ação no Supremo Tribunal Federal, a Arguição de Descumprimento de Preceito Fundamental 424, com o fim de definir claramente os limites e a competência dos Poderes. Por meio de análise de discursos referentes ao citado caso - por meio de notícias jornalísticas, de acesso aos autos e de observação de entrevistas coletivas para a imprensa e de sessões plenárias do Supremo Tribunal Federal - os autores explicitaram as hierarquias veladas entre Poderes da República, refletindo também como essas hierarquias se revelavam interna e externamente às instituições que os representavam, em especial o Judiciário. Assim, para fora, o Poder Judiciário se apresentava como um todo, único, indivisível, mas para dentro, o Poder Judiciário se apresentava como uma pirâmide, atualizando, o que os autores chamam de "estrutura de instâncias", que desigualavam seus membros, 
informalmente, revelando dimensões multifacetadas de desigualdade jurídica entre diversos atores de distintas instituições de poder que somente a empiria poderia estranhar e relativizar.

Na sequência, temos a publicação de Roberto Kant de Lima, Izabel Saenger Nuñez e Mauricio Mendonça de Carvalho que também a partir de análise de um caso ocorrido no Brasil - uma carga de fuzis apreendidos no aeroporto do Galeão no Rio de Janeiro em 2017 - que, por se tratar de um crime internacional, ao ser enviado para ser processado nos Estados Unidos acabou por gerar uma série de conflitos. Tais conflitos explicitaram a maneira contrastiva como agentes brasileiros e dos Estados Unidos lidaram com a prova, em função das diferentes regras que determinavam sua validade processual nos dois contextos, evidenciando os problemas e contradições da mera importação da custody chain enquanto cadeia de custódia no sistema jurídico-penal brasileiro. O primeiro é oriundo de um sistema jurídico orientado pelas lógicas adversarial e de mercado neoliberal enquanto que o segundo provém de um sistema jurídico orientado pelas lógicas inquisitorial e do contraditório. Utilizando dados etnograficamente construídos e o método comparativo por contrastes, os autores apontaram que o fenômeno de importação de institutos de maneira acrítica é um fato corriqueiro no campo jurídico brasileiro, em que os doutrinadores do Direito seguem louvando e buscando validar a inserção de instrumentos estrangeiros como fonte de aperfeiçoamento de nosso sistema, numa perspectiva evolucionista e generalizante. Tal fenômeno se deu sobretudo em relação aos institutos oriundos do modelo judicial dos EUA, como se representassem a solução para problemas de política judicial brasileira, a exemplo do que já ocorreu com o trial by jury e o plea bargain que influenciaram a construção do nosso tribunal do júri, os juizados especiais e a delação premiada, por exemplo. A comparação contrastiva entre sistemas da common law e da civil law demonstraram que eles têm princípios e finalidades muito distintas (GARAPON, PAPADOPOULOS, 2008), fazendo com que a circulação de institutos entre eles deveria ser cercada de muitos cuidados para que se atinja os efeitos desejados, o que na prática, como observaram os autores, não aconteceu no caso observado e descrito.

O terceiro artigo, de Welliton Caixeta Maciel, partiu de uma pesquisa etnográfica, realizada entre novembro de 2012 e novembro de 2013, em que o autor descreveu como se dá a utilização de tornozeleiras eletrônicas em homens autores de violência doméstica contra mulheres, como forma de garantir o cumprimento de medidas protetivas perante as vítimas, aplicadas por juízes, em Belo Horizonte, no Estado de Minas Gerais, e o posterior encaminhamento destes sujeitos a grupos reflexivos de gênero. Assim, tais atos institucionais 
almejavam romper os ciclos de violências entre homens e mulheres, como alternativa à justiça tradicional, puramente punitiva, com possibilidade de mudanças nos esquemas mentais, atitudinais e culturais dos sujeitos sociais diretamente envolvidos nesses casos penais, sobretudo, dos homens em relação às mulheres. $\mathrm{O}$ autor apontou que ao mesmo tempo em que tais políticas públicas procuravam proporcionar a alguns dos autores de crimes de violência doméstica a reflexão sobre suas ações individuais, também despertou sentimentos de indignação e revolta em outros. Embora ainda com reflexões parciais e em andamento sobre os dados da pesquisa, o autor apontou que mesmo depois desse processo interventivo, não existiam garantias de que os homens não se identificavam mais nem se deixavam conduzir segundo valores tradicionais de masculinidade, ou seja, a questão das masculinidades violentas era demandante de mudanças culturais mais significativas, inclusive nas instituições judiciais.

O artigo em seguida, de Marilha Gabriela Reverendo Garau, discute resultados de uma pesquisa etnográfica em audiências criminais na Baixada Fluminense do Rio de Janeiro e de Juzgados de Instrucción e Juicios Orales em Málaga, na Espanha, descrevendo e analisando, de forma contrastiva, discursos, práticas e moralidades presentes nas representações de juízes criminais ao valorar provas testemunhais em casos de tráfico de drogas. A partir de seus dados, a autora dispõe que apesar das proximidades de duas sensibilidades jurídicas pertencentes à tradição da Civil Law, Brasil e Espanha eram norteadas por lógicas distintas quanto à condução dos rituais de conhecimento e julgamento de fatos categorizados como crimes. No caso brasileiro, a característica da inquisitorialidade, manifestada na presunção de veracidade de documentos produzidos pelas instituições (fé pública), reforçava a presunção da culpabilidade do réu, assim como de inverdade de versões erigidas pela defesa ao longo de todas as etapas procedimentais e processuais na justiça criminal. No contexto espanhol pesquisado, de outra sensibilidade jurídica da tradição da Civil Law, embora também existisse um perfil de sujeição criminal demarcado, as versões expostas por réus e demais testemunhas eram levadas ao centro do processo judicial e a fase de julgamento proporcionava uma nova oportunidade de defesa. Ao colocar em contraste tais práticas judiciárias com as observadas no contexto espanhol, chamou atenção o fato de que no caso de Málaga, ao longo da investigação e, principalmente, no Juicio Oral, era desejável conhecer a versão do réu sobre os fatos. Tal característica expos que no sistema judiciário do país europeu a característica da oralidade, no procedimento processual penal, permitia ao réu e à defesa a mobilização das mais variadas modalidades de provas disponíveis, possibilitando a desconstrução de premissas inicialmente postas, sendo central na disputa por versões com potencial de validação, mesmo que dentro da lógica do 
contraditório. De tal modo, a condução do processo conseguia garantir a presunção de inocência do réu, já que as versões não eram, desde o ponto de partida, valoradas hierarquicamente. $\mathrm{O}$ que explicitou, por meio da comparação por contrastes, que nas práticas observadas no trabalho de campo realizado no Rio de Janeiro, o procedimento não era assimilado pelos operadores do Judiciário como uma garantia fundamental, mas sim como forma de reiteração e validação de culpabilidade antecipadamente construída pelas instituições policiais.

Izabel Saenger Nuñez compõe o quinto artigo desse dossiê, descrevendo, a partir de dados etnográficos, o espaço físico de uma das Varas do Tribunal do Júri do Rio de Janeiro, correlacionando sua organização espacial local com as concepções dos agentes sobre o fazer judicial. A autora descontruiu um ideário jurídico que expõe o plenário do Tribunal do Júri enquanto locus de rituais públicos e que por isso aproximariam a sociedade do fazer judicial. A representação no direito, de que este era um tribunal popular no qual juízes leigos (representados pelos jurados) possuíam protagonismo, se confrontava com a organização física do Tribunal do Júri como um todo e, também, do plenário. A forma como o espaço estava ordenado indicava que não eram os jurados a parte fundamental do ambiente. Na prática, o foco e a centralidade eram do magistrado, pois todos os presentes naquele campo para ele se voltavam, inclusive no espaço físico pesquisado, que tinha sido inaugurado há pouco tempo da época da pesquisa, tendo o plenário uma reconfiguração de auditório em declive, que poderia ser associado com a planta de um cinema ou de um teatro, de um local luxuoso. A autora expos como o Tribunal do Júri da Capital Fluminense foi especialmente remodelado no ano de 2012. Entre as alterações, uma das mais marcantes era o isolamento que separava a plateia do plenário, através da instalação de um vidro blindado entre eles, e a colocação dos jurados de costas para público, afastados do réu e de seus defensores, impedindo que os primeiros avaliassem as expressões dos envolvidos no caso. A existência desse vidro remeteu à ideia de uma vitrine, assim como a presença de um telão, remetia ao que poderia ser exibido e visto. Essa disposição espacial traduzia um judiciário que podia ser parcialmente visto, mas nem sempre podia ser acessado. Somando a isso, houve a alocação da mesa das testemunhas e réus de frente para o magistrado e Ministério Público (MP) e de costas para os jurados. Toda essa disposição física desse espaço judicial implicou em uma importante transfiguração em sua dinâmica, descartando a atuação decisiva dos jurados e embaraçando o seu contato com a prova que deveria ser produzida, para eles, em plenário. Essas e várias outras descrições da autora apontaram para a centralização do juiz e a reconfiguração dos jurados enquanto coadjuvantes no julgamento pelo Tribunal do Júri, em um processo em que estes deveriam ser centrais. 
Em seguida, há o artigo de Gabriel Borges da Silva que analisou como se dava a produção sistemática de mortes em uma favela do Rio de Janeiro, em decorrência de práticas de violência estatal, especificamente durante a pandemia do vírus COVID-19, e como não eram contempladas ou sequer contestadas em nosso sistema de justiça. Metodologicamente, esse trabalho é uma extensão de pesquisa de doutorado realizada por meio de trabalho de campo com observação participante de 2014 a 2019 na favela nomeada ficticiamente como Vale. Para o presente artigo, a pesquisa se deu por meio de conversas informais nas redes sociais disponíveis via aplicativos de celular a respeito dos impactos do Corona Vírus naquele recorte espacial ao longo de 2020, além de conversas virtuais informais com interlocutores. Com a pandemia, o COVID-19 apareceu como mais uma das ameaças enfrentadas pelos moradores do Vale, ao passo que as rotineiras práticas policiais como incursões do "caverão" (categoria nativa para caveirão, veículo blindado da Polícia Militar do Rio de Janeiro com a estética de um tanque de guerra), mesmo com liminar concedida em junho de 2020 pelo ministro Edson Fachin do Supremo Federal Tribunal suspendendo-as, continuavam produzindo mortes mesmo em meio à situação que toda sociedade enfrentava. Assim surge a categoria nativa "caverão vírus" que explicitou como a preocupação dos moradores do local pesquisado com o caverão era maior do que a preocupação com o contágio e eventual morte pelo Corona vírus. Partindo desse contexto, o autor expos que apesar da garantia igualitária do direito à vida, presente em nossa Constituição da República Federativa do Brasil de 1988, tais mortes não eram preocupação do sistema de justiça criminal, sendo inclusive legitimadas na própria conduta de quem morreu, como na ideia de que se morreu foi porque "deu mole" - estava no lugar e na hora errada, mesmo sendo inocente - justificando tanto as motivações estatais e quanto à necessidade de se produzir tais óbitos. Assim, foram evidenciados fatores marcantes próprios da desigualdade brasileira e que configuram um misto de infortúnios para sujeitos que morreram, seja por COVID-19, seja pelas operações policiais, a depender de seu status social e/ou da sua cor.

O sétimo artigo é de Rodrigo Ghiringhelli de Azevedo e Michelle Karen Batista dos Santos que realizaram tanto análise documental de dados oficiais de pesquisa no âmbito do programa “Justiça para o Século 21” articulado pela Associação dos Juízes do Rio Grande do Sul, quanto análise de resultados de estudos de casos efetuados no âmbito de pesquisa de campo em três Juizados de Violência Doméstica no Estado do Rio Grande do Sul para pensar as práticas da justiça restaurativa no Brasil. Os autores apontaram que a justiça restaurativa surgiu como um modelo radicalmente diferente da administração tradicional de conflitos, constituindo uma nova maneira de pensar o crime e a pena, efetuando um movimento histórico-científico, 
no que tange ao deslocamento da vítima do lugar meramente subalterno de interesse da justiça criminal, principalmente do processo penal. Os programas brasileiros de justiça restaurativa contaram com o protagonismo do Poder Judiciário e com um ideal de democratização da justiça de cima para baixo. Além disso, havia uma intensa influência etnocêntrica, notadamente estadunidense e da Europa Ocidental. Entretanto, os autores apontaram que no Brasil, os limites institucionais e instrumentais para essas políticas públicas eram inúmeros, resultando em uma justiça restaurativa que servia de acessório ao sistema de justiça criminal tradicional, legitimando, paradoxalmente, suas funções que são profundamente diversas dos princípios e valores da justiça restaurativa originalmente construídos. A mera regulamentação legal (Resolução n. 125/2010, seguida da Resolução n. 225/2016, ambas do Conselho Nacional de Justiça em conjunto com a Lei ${ }^{\circ} 11.340 / 2006$ ) e a autonomia dos núcleos de justiça restaurativa não permitiram que tal modelo de justiça fosse de fato aplicada nos Juizados de Violência Doméstica contra Mulher. Muito pelo contrário, o que foi observado na pesquisa foi a necessidade do Estado de ofertar respostas às mulheres vítimas dentro de um sistema repressivo e punitivo, impedindo a percepção judicial da singularidade de cada caso, massificando os conflitos como se todas as relações fossem estruturadas da mesma forma.

O artigo a seguir, de Bruna Angotti, apresentou suas questões de usos de metodologias combinadas ao realizar pesquisa etnográfica sobre casos de infanticídio julgados no Tribunal do Júri de São Paulo entre 2015 e 2018: pesquisa jurisprudencial, trabalho de campo, análise de discurso nos autos por meio do software NVIVO, análise de discursos doutrinários, entrevistas formais e informais. Assim, a autora realizou pesquisa jurisprudencial nos sites de todos os 27 tribunais estaduais e do Distrito Federal, do Superior Tribunal de Justiça (STJ) e do Supremo Tribunal Federal (STF), proferidos entre 2005 e setembro de 2015. E através do NVIVO, software que auxiliou na sistematização dos dados e análise qualitativa, foi feita a leitura dos acórdãos e a organização das categorias nativas recorrentes nesses processos, criando códigos e marcadores para a sistematização do conteúdo dos documentos judiciais, facilitando, tanto as suas leituras quanto a percepção de correlações entre conteúdos. Foi possível identificar, assim, quais eram as "vozes" que se contrastam, as mais eloquentes, as que predominam, as que sussurravam e aquelas que possuíam seus discursos limitados pelas perguntas daqueles que orquestravam o "coral”. Para além dos documentos judiciais a autora também observou sessões nas quais mulheres acusadas pela morte de seus recém-nascidos estavam sendo julgadas. Um caso judicial era formado tanto por documentos escritos quanto por momentos orais - que eram resumidamente documentados nos autos processuais. $\mathrm{O}$ fazer 
judicial, portanto, era composto também pelas sessões e audiências, momentos nos quais as partes eram ouvidas, bem como outros personagens processuais, como testemunhas e especialistas. E por meio do uso desses multimétodos de pesquisa articulados entre si a autora percebeu e descreveu como o processamento desses casos não era uniforme. Apesar das histórias envolvendo mulheres acusadas das mortes de seus/suas recém-nascidos serem aparentemente semelhantes entre si, tanto nos casos e acórdãos analisados, quanto na literatura estrangeira sobre o tema, tais histórias, na prática, eram tratadas no sistema de justiça criminal de maneira bastante heterogênea, assim como suas categorizações penais e os desfechos dos casos que mudavam de acordo com o andamento processual, as moralidades dos atores e atrizes do sistema de justiça. Desde o modo como eram classificados pela autoridade policial, denunciados pela promotoria, defendidos, processados e julgados no Judiciário, houve desfechos muito distintos entre si, evidenciando uma "Torre de Babel" jurídica na administração dos casos analisados.

A imprevisibilidade das classificações penais, dos procedimentos, interpretações judiciais e desfechos em cada caso não estava apenas na assimetria dos julgamentos, mas também nos posicionamentos doutrinários penais e médico legais, que eram também muito discrepantes entre si, inclusive nos entendimentos do que era o "estado puerperal" e como comprová-lo. Questões observadas e estranhadas justamente pelo movimento da pesquisadora em “estar lá", em campo, em sessões do Júri, dialogando, observando, convivendo e participando com os nativos, com documentos e com doutrinas enquanto discursos a serem ouvidos. $\mathrm{O}$ estudo das práticas judiciárias permitiu uma interlocução com o campo empírico que incorporou à produção do saber jurídico os significados que os operadores do campo conferem à lei e às normas, permitindo uma percepção mais completa dos fenômenos e institutos jurídicos.

O nono artigo é de Klarissa Almeida Silva Platero que analisou o fluxo do processo de incriminação e elementos determinantes para se ter uma sentença condenatória para casos de acusados de homicídio doloso consumado em Belo Horizonte no Estado de Minas Gerais. Para tanto, a autora construiu uma base de dados quantitativos a partir da análise do conteúdo de denúncias que foram oferecidas por promotores de justiça, um conjunto formado por 154 processos de indivíduos denunciados por homicídio doloso consumado entre janeiro de 2004 e dezembro de 2005 para o recorte espacial proposto. Posteriormente, acompanhou anualmente, desde 2007 até 2013, as fases judiciais em que os processos originados por essas denúncias se 
encontravam, de modo a observar o processo de incriminação desses indivíduos ao longo do tempo por meio de consulta realizada no site do Tribunal de Justiça de Minas Gerais. A principal técnica de análise adotada foi a das correlações estatísticas por tipologia a fim de descrever e compreender padrões desde o oferecimento da denúncia até a sentença condenatória na segunda fase do Tribunal do Júri. A observação desse conjunto de dados quanto ao fluxo do processo de incriminação pelo rito do tribunal do júri mostrou que $92,7 \%$ dos denunciados que foram submetidos à decisão do conselho de sentença foram condenados e 5,5\% foram absolvidos, ou seja, a grande maioria das denúncias de eventos tipificados como homicídio doloso resultou em condenação, decorridos cerca de 9 anos da acusação pública. Isso evidenciou que na prática há uma culpabilidade a priori dos acusados de homicídio doloso no processo penal, contrastando com o princípio jurídico-doutrinário da presunção de inocência que deriva do artigo $5^{\circ}$, LVII da Constituição da República Federativa do Brasil de 1988, que dispõe que "ninguém será considerado culpado até trânsito em julgado de sentença penal condenatória". Além disso, a pesquisadora verificou que as taxas de condenação para os indivíduos incriminados por homicídios relacionados a drogas e homicídios relacionados a conflitos cotidianos são, respectivamente, $96,5 \%$ e $86,6 \%$, ou seja, uma vez denunciado, era quase certo que o indivíduo seria condenado, principalmente se o acusado compusesse o tipo social "traficante". Tais constatações indicaram uma maior reação judicial aos homicídios envolvendo tráfico de drogas e, possivelmente, a continuidade da construção social e institucional da sujeição criminal, uma demonstração que a culpabilidade a priori do processo penal tinha um público alvo.

Em análise semelhante, mas voltada para o crime de tráfico de drogas, há o artigo de Ana Rita Nascimento, Lívia Lages, Daniely Reis e Juliana Neves que pesquisaram como se dava o papel e atuação do defensor - público ou particular - no curso do processo penal para casos penais de tráfico de drogas a partir de processos finalizados durante o período de 2007 a 2017, em Belo Horizonte, Minas Gerais. Este artigo é fruto de uma pesquisa maior, intitulada "Fluxo do Processo de Tráfico de Drogas em Belo Horizonte", financiada pelo Conselho Nacional de Desenvolvimento Científico e Tecnológico $(\mathrm{CNPq})$ e realizada pelos pesquisadores do Centro de Estudos em Criminalidade e Segurança Pública (CRISP) da Universidade Federal de Minas Gerais (UFMG), que seguiu a metodologia de fluxo longitudinal retrospectivo em que, a partir da análise dos casos já encerrados, foi feita a reconstituição do crime desde o seu registro até o seu desfecho no sistema de justiça criminal. Para o prosseguimento da pesquisa, o Tribunal de Justiça de Minas Gerais (TJMG) cedeu aos pesquisadores um espelho de todos os casos de tráfico de drogas encerrados entre 2007 e 2017 
e, a partir deles, foi construída uma amostra de processos penais representativa por ano. $\mathrm{O}$ TJMG também permitiu a consulta aos autos processuais, a qual se deu no arquivo do tribunal, sendo consultados e utilizados 748 dos 15.246 processos de tráfico de drogas arquivados entre 2007 e 2017 em Belo Horizonte. As autoras demonstraram que em 1495 indiciados, 87\% eram do sexo masculino, $74 \%$ eram pretos ou pardos, $62 \%$ jovens e $51 \%$ não tinham ensino fundamental completo. Assim, as pessoas processadas criminalmente correspondiam ao perfil de quem era socialmente considerado como "bandido". Desses casos, a defensoria pública atendeu 54\% (801 casos) dos réus da amostra, enquanto que os advogados particulares foram responsáveis por 36\% (542 casos). Em 4\% (57 casos) houve a atuação de advogados dativos e em $6 \%$ (94 casos) não foi possível acessar os dados sobre a defesa da parte, de modo que no banco de dados consta a ausência desta informação. No que tange aos resultados, não foi encontrada diferença estatisticamente significativa entre as defesas exercidas por advogado particular ou por defensor público, tanto no que se refere ao transcurso do processo, quanto ao resultado final alcançado na sentença. Segundo as autoras, isso ocorreu porque o sujeito, quando indiciado por tráfico, já era previamente julgado como culpado, sendo os argumentos da defesa incapazes de alterar essa percepção da família judicial (NUÑEZ, 2021), ou seja, a defesa cumpria um papel meramente cerimonial na maioria dos casos. Além disso, os dados indicaram que a sentença judicial tende a acolher sobretudo os pedidos do Ministério Público, demonstrando que a defesa do acusado, em si, tinha pouca capacidade de influenciar no desfecho do caso.

O décimo primeiro artigo é de Maria Stella Faria de Amorim e Michel Lobo Toledo Lima que apresentaram uma compilação de pesquisas e reflexões realizadas desde 1999 acerca dos Juizados Especiais Estaduais e Federais, desenvolvidas no âmbito da Faculdade de Ciências Jurídicas e Sociais da Universidade Iguaçu, no Programa de Pós-Graduação em Direito da Universidade Gama Filho e no Programa de Pós-Graduação em Direito da Universidade Veiga de Almeida, respectivamente, sendo esta última com projeto de pesquisa, ainda em andamento, executado no Núcleo de Pesquisa em Processos Institucionais de Administração de Conflitos. Os autores analisaram dados de pesquisa de campo realizada nos juizados especiais, em especial os federais, com observação direta de audiências e entrevistas abertas com partes e com operadores atuantes nesses campos, entre 2004 e 2006, em conjunto com dados quantitativos sobre tais observações em campo. Os dados quantitativos foram inicialmente obtidos em dois juizados federais, mediante autorização dos respectivos magistrados titulares de tais varas, sendo disponibilizados doze mil processos findos nos juizados federais no ano de 
2007. Após analisada a representatividade dos processos autorizados para consulta, foi calculada uma amostra aleatória de duzentos e oitenta processos originados de três juizados federais do Rio de Janeiro e um de São Gonçalo, o que permitiu traçar o perfil dos conflitos predominantes, assim como o perfil dos demandantes nesses juizados. Os principais conflitos apontaram duas agências federais como as principais rés nos juizados federais, em suas competências previdenciárias e cíveis: o Instituto Nacional do Seguro Social (INSS) com 51\% das ações e a Caixa Econômica Federal (CEF) com 46,4\% de ações movidas por pessoas físicas, desprezadas outras ações $(2,6 \%)$. Durante entrevistas realizadas com representantes do INSS e da CEF - seus advogados ou procuradores - nas ações em trâmite nos juizados federais, estes operadores diziam que não podiam conciliar ou fazer acordos pois eram responsáveis pelo patrimônio da ré e que estavam ali para protegê-lo, porque ele era público e inegociável com particulares. Assim, eles compareceram às audiências para resguardar o patrimônio da União, indisponível para acordos com particulares, não podendo este patrimônio ser tocado, sem que houvesse decisão judicial que o permitisse. Segundo os autores, a maior surpresa recaiu sobre o papel da "peça de defesa padrão" usada pelos réus (no caso a CEF e o INSS) para contestar os pedidos dos autores; $29,3 \%$ dos réus utilizaram esse tipo de contestação, sendo que 60,3\% dos arquivamentos dos processos se deram por essa contestação. A citada peça processual motivou a negação, em $1^{a}$ Instância, de aposentadorias, pensões e correção de benefícios aos reclamantes. Os pesquisadores apontaram que assim como em outras pesquisas sobre o mesmo campo, foi constatado que as práticas processuais nesse contexto possuíam linhas acentuadamente inquisitoriais. Se, de um lado, havia um tripé probatório bastante flexível (ANGELO. CARDOSO DE OLIVEIRA, 2021), que era composto pela produção de prova documental, pela inquirição das partes autoras e das testemunhas e pela inspeção judicial, sem um padrão explícito, de outro, havia certa padronização de defesa nas contestações automáticas, estas com fé pública emprestada pelo cartório que produzia tais peças, em favor dos réus compostos em sua esmagadora maioria pelo INSS e CEF, respectivamente -, em audiências que os desfavorecem, ato expresso na categoria nativa "peça de defesa padrão". Assim, de mobilizadores da democratização judicial e de instituições com potencial de romper com concepções tradicionalmente arraigadas no direito e na justiça brasileiros, os juizados especiais se tornaram mais caracterizados pelos parâmetros delimitadores de práticas judiciais tradicionais, minimizando ou suprimindo os procedimentos mais flexíveis que lhes foram atribuídos pela legislação que os criou e que permanece vigente. Imaginados enquanto microssistemas capazes de provocar rupturas com o passado e de mitigar traços antirrepublicanos e antidemocráticos que ainda se insinuam no presente, os juizados brasileiros 
adotaram padrões já ultrapassados na contemporaneidade e conciliando-se com a tradição jurídica pautada num Estado tutelar e inquisitorial.

O artigo seguinte, de Fábio de Medina da Silva Gomes analisou os acordos judiciais nas audiências trabalhistas envolvendo trabalhadoras domésticas remuneradas, descrevendo e problematizando como eram estabelecidos os acordos nessas audiências. Para tanto, o autor realizou trabalho de trabalho de campo com observações diretas das referidas audiências e entrevistas não estruturadas e semiestruturadas com vários interlocutores do campo como advogados, juízes, empregadores domésticos, empregadas domésticas, diaristas, sindicalistas e técnicos judiciários. As diversas representações jurídicas observadas em campo - discursos dos magistrados e dos advogados e a própria condução das audiências - enfatizavam a necessidade dos acordos judiciais como forma privilegiada de administrar os conflitos trabalhistas, sendo sempre simbolizados pela expressão nativa "todos ganham", sendo realizados "por livre e espontânea vontade". Porém, para além do mero discurso institucional, observou-se que a empregada doméstica, na prática, era levada a aceitar um acordo "com desconto" em relação aos valores da sua demanda original, tendo o processo como ameaça, pois o conflito sobre vínculo empregatício e valores devidos à parte demandante poderia estender a discussão até as instâncias superiores, levando muitos anos para ser administrada e com resultado incerto. Para levar a cabo tais acordos, toda uma simbologia era empregada, comumente destacando a desigualdade entre a empregada doméstica e o juiz - que como foi descrita numa fala de um magistrado que ele "descobre as coisas olhando", no "faro" - ou mesmo nas falas dos advogados das empregadas, conforme demonstrou a fala "nós, os advogados forçamos mesmo, até quando a pessoa não quer o acordo. Imagina se não tem acordo. É um caos”. Do início ao término da audiência, tudo (re)lembrava o par hierarquia e desigualdade, pois os acordos, nessa lógica de processo como ameaça aos demandantes de direitos, eram praticamente unilaterais e geralmente contra os interesses do trabalhador. O autor dispôs que a Emenda Constitucional $\mathrm{n}^{\circ}$ 73 de 2013 visou ampliar a proteção legal dos empregados domésticos, uma tentativa de um avanço no sentido de igualar pessoas quanto a direitos trabalhistas. Entretanto a pesquisa demonstrou que tal modelo de justiça tratava-se de uma cultura jurídica rigidamente desigual.

O próximo artigo do dossiê, de Klever Paulo Leal Filpo e Felipe Dutra Asensi teve por objeto de pesquisa os litígios de saúde, disputas surgidas quando pessoas demandantes de certas prestações de serviço ou medicamentos no campo da saúde pública-como entrega de remédios, insumos, realização de exames e cirurgias, etc. - tiveram tal pretensão negada pela 
administração pública, originando um conflito de interesses. Assim, motivada em reduzir os índices crescentes de judicialização de conflitos dessa natureza no estado do Rio de Janeiro, a Procuradoria Geral do Estado e outras instituições buscaram formas consensuais para administrar conflitos entre cidadãos e entes estatais com o fim declarado de diminuir a propositura de ações judiciais ligadas à saúde pública por meio da Câmara de Resolução de Litígios de Saúde (CRLS). Partindo desse contexto, os autores realizaram em um primeiro momento, análise de documentos referentes aos materiais de divulgação da CRLS encontrados em diversificados veículos de comunicação, a fim de perceber os discursos institucionais perante a população. E em um segundo momento, foram explorados dados de trabalho de campo com observações diretas e entrevistas informais, realizada entre maio de 2019 e maio de 2020 , na sede da CRLS situada no centro da cidade do Rio de Janeiro. Os pesquisadores apontaram o paradoxo entre a proposta da CRLS, enquanto Modelo Alternativo de Resolução de Conflitos, em repelir a busca pela prestação jurisdicional - o ajuizamento de uma ação judicial - e as suas atuações institucionais, pois nas suas mediações extrajudiciais estavam presentes os responsáveis pela promoção de direitos dos usuários, tal como a Defensoria Pública que estava institucionalmente encarregada do ajuizamento das respectivas ações judiciais, caso o usuário não desejasse tentar uma solução consensual, ou quando esta se mostrava inviável. Além dessa confusão entre lógicas judiciais e extrajudiciais "mescladas", os autores problematizaram tal questão por meio de um caso de um homem de 50 anos que havia celebrado acordo na CRLS para a realização de cirurgia de hérnia de disco em hospital público, mas sem que o seu agendamento fosse efetuado mesmo após mais de 4 meses após a mediação. O caso evidencia como tais medidas "inovadoras" fragilizavam quem já se encontrava em posição de vulnerabilidade no que tange demandas de saúde pública. Assim como o devido processo legal, o CRLS muitas vezes não conseguiu proteger o cidadão do Estado, mas produziu uma proteção do Estado contra cidadão.

O décimo quarto artigo é de Marcella do Amparo Monteiro Freire e de Michel Lobo Toledo Lima que descreveram e analisaram audiências judiciais de casos de pensão alimentícia para ex-cônjuges em Varas de Família no Estado do Rio de Janeiro entre 2019 e 2020, por meio de trabalho de campo com observações diretas de tais audiências e entrevistas abertas com operadores do campo. Os autores problematizaram que há uma tensão paradoxal entre práticas e ideais doutrinários do direito, no campo judicial observado, explicitando uma contradição percebida entre as moralidades situacionais que orientam as decisões dos juízes, o que era traduzido na categoria nativa "cada caso é um caso", e o princípio da segurança jurídica, 
pautado, principalmente, na previsibilidade e transparência nas decisões judiciais em casos semelhantes. Metodologicamente, a pesquisa foi composta por três métodos em diferentes momentos, em função do isolamento social e da interrupção de todos os serviços prestados pelo Poder Judiciário impostos pela pandemia do Corona vírus: a pesquisa de campo com observação direta das audiências presenciais por um período de três meses, semanalmente, sendo dezenove audiências nas Varas de Família; as entrevistas abertas, sem questionários formulados anteriormente, realizadas com cinco magistrados titulares de Varas de Família, todos do Tribunal de Justiça do Estado do Rio de Janeiro; por fim foram observadas presencialmente doze audiências virtuais, também em Varas de Família no Rio de Janeiro. As observações demonstraram que as diferentes moralidades pessoais dos juízes acerca das pessoas em demanda judicial orientavam suas decisões, havendo uma construção particularizada e implícita de quais ex-esposas eram merecedoras de pensões alimentícias vitalícias ou provisórias, de acordo com a mensuração dos valores e moralidades dos juízes, enunciadas em expressões nativas como "Você errou! O amor acaba" e "Já está na hora de trabalhar", "Já descansou bastante". Entretanto, nas entrevistas realizadas com os magistrados, paradoxalmente todos explicitaram haver um consenso doutrinário e jurisprudencial de critérios norteadores das suas decisões, como a idade dos envolvidos e o tempo de casamento, para concessão dos tipos e valores de pensão alimentícia, ao mesmo tempo em que todos também afirmaram que "cada caso é um caso", deixando as decisões abertas a um número incontável de possibilidades de desfechos, sempre a cargo do casuísmo particularizado e dos valores morais implicados no caso, do ponto de vista de "moralidades situacionais" (EILBAUM, 2012) empregadas em cada caso pelos juízes, sem que existissem critérios explícitos aptos a orientar os resultados a serem esperados pelos jurisdicionados, acabando por gerar insegurança jurídica e uma falta de compreensão das decisões pelos jurisdicionados.

A seguir, há o artigo de Pedro Heitor Barros Geraldo e Lucia Lambert de Passos Ramos que analisaram contrastivamente a socialização profissional de juízes em contextos institucionais distintos, o brasileiro e o francês, descrevendo os diferentes significados que podem ser dados ao aprendizado das práticas profissionais entre os magistrados, em especial, a questão das consequências dos erros praticados. O recorte da pesquisa se deu com juízes do trabalho recém-empossados no Tribunal Regional do Trabalho do Rio de Janeiro, a partir da participação observante do curso de Formação Inicial (CFI) da Escola Judicial 1 (EJ1), enquanto que, no contexto francês, construiu-se dados de pesquisa de campo com observação de audiências com juízes de proximidade - função criada em 2004 voltada para julgar os 
pequenos casos da vida cotidiana - em cinco fóruns diferentes do sudeste da França. Assim, os autores apresentaram que no contexto francês, o erro é uma parte importante do "aprender na prática". Ele não produzia consequências negativas para a reputação profissional no âmbito de suas relações profissionais, ou seja, o erro era tolerável e servia unicamente ao aprendizado daquele saber considerado pelos membros de um grupo ocupacional como algo profissional. Nesse contexto, o auditeur de justice não era ainda um juiz no exercício de suas funções, mas assumidamente um novato. Era importante que ele se socializasse com as práticas e os limites de sua profissão na École Nationale de la Magistrature, permanecendo nessa condição por 30 meses. O erro fazia parte de um aprendizado não apenas individual, mas que também tinha uma performance publicamente e coletivamente escrutinada pelos colegas juízes. Essa maneira de instruir-se com o erro era bastante diferente daquela observada na socialização nas práticas jurídicas brasileiras. O modelo da EJ1 se orientava por uma prática de aprendizado que escondia o erro ou o atribuía a outro, a exemplo da expressão nativa “foi induzido a erro". Nessa lógica, os juízes brasileiros aprendem que ou eles nunca erram, ou que quando comentem alguma falha profissional, esta ocorreu porque outro autor - um advogado, o escrivão, o analista judiciário, o secretário, etc. - o induziu a errar. Essa forma de aprender no trabalho, do caso brasileiro, era muito distinta do "aprender na prática" francês. Os erros praticados pelos profissionais que aprendiam no trabalho, no nosso caso, eram tratados como transgressões pontuais. Os próprios magistrados não colocavam em questão as suas práticas, seus erros, que eram tidos como uma reprodução indesejada tanto publicamente quanto internamente. É uma pedagogia do sigilo e da denúncia do erro do magistrado. Isto significava que as questões importantes para o aprendizado do exercício da profissão, inclusive com os erros dos colegas magistrados, não eram construídas enquanto problemas institucionais, mas como erros pontuais e induzidos por outros atores. Desse modo, nossas instituições não foram capazes de (re)produzir políticas de identificação e preservação de um saber prático transparente para os membros internos. Nem mesmo as eventuais punições de juízes que cometeram erros em decisões não colocavam em pauta a reprodução desse conhecimentocorporativo, mas apenas as condutas individuais de cada profissional. Além dessas questões, a comparação por contraste explicitou que no caso francês a prática informava e construía a teoria no campo jurídico, enquanto que no caso brasileiro há um abismo existente entre a doutrina, aprendida na Faculdade de Direito, e a prática jurídica, presente nos diferentes contextos profissionais jurídicos. 
Finalmente, o artigo de Hector Luiz Martins Figueira analisou a tradicional cultura bacharelesca brasileira, em especial dos estudantes da graduação em Direito. O autor realizou pesquisa etnográfica com observação participante no contexto do ensino jurídico nas universidades privadas cariocas. $\mathrm{O}$ autor apontou que no geral os docentes especialistas e mestres eram contratados pela instituição de ensino para ministrar diversas disciplinas ao mesmo tempo, mesmo que não fossem das suas áreas de expertise ou de atuação profissional. Não era incomum observar advogados ensinando sociologia, antropologia e filosofia por meio de mapas mentais, fluxogramas e métodos mnemônicos de memorização. Além disso, o autor também problematizou um discurso comum observado no campo, de que a profissão de professor era um "bico", uma complementação de renda, sem preocupação com a pesquisa ou a construção de um conhecimento emancipador e reflexivo. Somado a isso, também foi explicitado o ponto de vista dos alunos, que apresentaram em comum um discurso de fetichização da formação jurídica, buscada pela vontade de ser reconhecido socialmente como "doutor", em busca de um desejado "conhecimento jurídico" e "reconhecimento social" conquistado com a formação. Tais descrições apontaram questões interessantes. A primeira delas, se deu com a descrição da busca por destaque social dentro de uma sociedade desigual e hierárquica como a brasileira, por meio do diploma graduação em Direito. Com a formação concluída, e o diploma conquistado, seja ele na graduação, especialização, mestrado ou doutorado, no Brasil, os interlocutores afirmavam que possuíam mais chances de se desigualar, para cima, dos seus antigos pares, assumindo um novo status nas relações sociais, acima do mero extrato de cidadão. Além disso, o diploma de ensino superior garantia, por exemplo, o direito à prisão especial, explicitando que a hierarquia de tratamento também constava na nossa legislação. Essa postura contrasta fortemente com a de outras sociedades mais democráticas e igualitárias, como os Estados Unidos, por exemplo, em que a cidadania não necessita de certificações acadêmicas para ser exercida. A segunda questão se deu com a dicotomia entre o que é tido como "teoria", que é ensinado nas universidades de Direito, e a prática, que é ensinada no cotidiano profissional dos operadores do campo. Algo que um juiz, em uma das entrevistas descritas, explicitou bem quando afirmou que "muitos advogados recém-formados e também com algum tempo de formado, não sabem como se conduzir e agir em uma audiência”. Isso também se verificou com a docência universitária quando o autor descreveu que muitas disciplinas eram lecionadas por professores que não tinham a experiência no referido campo do conhecimento a ser ensinado. Tais descrições explicitaram que o campo do Direito brasileiro não formulou uma teoria explicativa, consensual e explícita de suas práticas, algo também confirmado pelas inúmeras correntes doutrinárias, entendimentos jurisprudenciais 
e decisões monocráticas tão díspares entre si acerca de um mesmo assunto ou casos semelhantes. Segundo o autor, a pedagogia implícita do nosso Direito, seja na academia, seja nos Tribunais, foi voltada para o dissenso, o argumento de autoridade e a hierarquização da sociedade, contrariando suas diretrizes curriculares formuladas pelo Ministério da Educação (MEC), pautadas pela adequada formação teórica, profissional e prática do aluno, além de uma formação voltada para o exercício e construção da cidadania.

\section{ENTRE TRADIÇÃO E TRANSFORMAÇÃO: POR UM CAMINHO PARA ALÉM DAS AUTO INTERPRETAÇÕES INSTITUCIONAIS}

Esse dossiê visa contribuir para o campo do Direito, da Sociologia do Direito, da Antropologia do Direito, e para os estudos sobre a relação entre sociedade e instituições judiciais e extrajudiciais, problematizando os processos de administração institucional e não institucional de conflitos e, sobretudo, os processos de demanda de direitos e de reconhecimento por parte de diversos atores.

Também representa um esforço na contribuição para campos de pesquisa caracterizados pela dificuldade de operacionalização de pesquisas quantitativas e qualitativas acerca dos sistemas judiciais e extrajudiciais no Brasil, onde os registros de seus atos e bases de dados são comumente incompletos e fragmentados, construídos por cada instituição que compõe os sistemas judiciais conforme critérios e documentos que interessam aos interesses institucionais particulares de cada uma. Não há em tais instituições a preocupação com a transparência indispensável para a verificação do desdobramento desses dados e seus usos em procedimentos posteriores que possibilitem acompanhar e avaliar, contrastivamente, a efetividade dos processos de administração de conflitos em cada instituição, evidenciando a inexistência da tradição de um sistema oficial universalizado e transparente de registros, que incorpore informações sobre todos os fluxos e momentos procedimentais.

Apesar de ser uma boa ferramenta de análise, os registros e os dados quantitativos sobre o Judiciário no Brasil tradicionalmente expõem, ao menos, três problemas (LIMA, M., 2015, p. 52): a ausência de uma tradição institucional de coleta e publicização de dados e de análises estatísticas; o sigilo que as instituições desse campo comumente fazem de dados concernentes 
aos seus próprios atos e registros; além da falta de qualidade e a baixa confiabilidade de parte dos poucos dados coletados e publicamente divulgados.

Sobre a primeira questão, embora tenhamos instituições que produzam dados em âmbito nacional, como o IBGE - Instituto Brasileiro de Geografia e Estatística - que, por exemplo, através da sua série "Estatísticas do Século XX" disponibiliza dados históricos relativos à justiça no Brasil; o DATASUS - departamento de informática do sistema único de saúde - que tem a responsabilidade de coletar, processar e disseminar informações sobre saúde; o InfoPen - Sistema Integrado de Informações Penitenciárias - que organiza e publica o registro de indicadores gerais e preliminares sobre a população penitenciária do país; e o IPEA - Instituto de Pesquisa Econômica Aplicada - com atividades de pesquisa voltadas às ações governamentais para a formulação e reformulação de políticas públicas; entre poucos outros, trata-se de instituições com dados ainda recentes e que não estão, ao menos diretamente, vinculadas às instituições judiciais.

O CNJ - Conselho Nacional de Justiça - por meio do Departamento de Pesquisas Judiciárias tem pesquisas e dados quantitativos acerca do fluxo de processos judiciais, sendo uma das poucas instituições diretamente ligadas ao judiciário e com produção de dados públicos nacionais referentes aos atos judiciais. Porém, as variáveis escolhidas para análise pelo CNJ desprivilegiam os microdados, possuindo poucos detalhes de diagnóstico, avaliando apenas algumas características dos movimentos processuais, o número de funcionários e orçamento das comarcas e Tribunais por Estado e por ano, sem considerar os tipos de demanda, formas de resolução dos conflitos, o perfil e a satisfação das partes conflitantes com as respostas institucionais para suas demandas.

Acerca da segunda questão, há o sigilo, em que é muito importante relembrar a característica inquisitorial que norteia o campo do Direito, havendo ainda a ideia de que uma verdade deve ser investigada sigilosamente e registrada por escrito no transcorrer dos procedimentos e processos judiciais. O sigilo, a vigilância e o registro, são ferramentas de acusação do Estado, e não de defesa dos envolvidos (LIMA, R., 2010, p. 34-35). Disso também decorre a rejeição das instituições judiciais na exposição de suas práticas internas, de seus registros e da publicização de erros ou problemas desdobrados dessas práticas internas. Questões que ainda são empecilhos para pensarmos o Brasil a partir dos nossos próprios registros, informações, dados e conceitos para descrever os nossos fenômenos sociais, desdobrando-se em um verdadeiro calcanhar metodológico entre nós (SOARES, 2005). 
Visa-se assim, diante dos desafios e percalços das pesquisas com o Direito, reforçar e ampliar a característica de diálogo entre campos do conhecimento e instituições, buscando aumentar qualitativa e quantitativamente o desempenho científico do nosso Direito, contribuindo para a sua competitividade internacional da pesquisa brasileira acerca desse campo.

Desejo profícua e inquietante leitura para todos!

\section{REFERÊNCIAS}

AMORIM, Maria Stella de. Conflitos no Mercado de Bens e Serviços: Consumidores e Consumidos. In: Maria Stella de Amorim e Roberto Kant de Lima (Org.). Administração de Conflitos e Cidadania: problemas e perspectivas. Rio de Janeiro: Autografia, 2017, v. 1, p. 268280.

AMORIM, Maria Stella de. LIMA, Michel Lobo Toledo. LIMA, Roberto Kant de (Org.). Administração de conflitos e cidadania: problemas e perspectivas IV. V. 33. Rio de Janeiro: Autografia, 2020.

AMORIM, Maria Stella Faria de. BAPTISTA, Bárbara Gomes Lupetti. DUARTE, Fernanda. LIMA, Michel Lobo Toledo. LIMA, Roberto Kant de (orgs.) Dossiê: Pesquisa em Direito na Perspectiva Empírica: práticas, saberes e moralidades. In Antropolítica: Revista Contemporânea de Antropologia. Niterói. N. 51, 2021.

ANGELO, Jordi Othon. CARDOSO DE OLIVEIRA, Luís Roberto. Entre documentos, inquirições e inspeções: a trama da produção de provas em processos de aposentadoria rural nos Juizados Especiais Federais. In: Dossiê Pesquisa em Direito na Perspectiva Empírica: práticas, saberes e moralidades. Antropolítica: Revista Contemporânea de Antropologia. Niterói. N. 51, 2021.

AZEVEDO, Rodrigo Ghiringhelli. Juizados Especiais Criminais: Uma abordagem sociológica sobre a informalização da Justiça Penal no Brasil. Revista Brasileira de Ciências Sociais, São Paulo, v. 16, n.47, p. 97-110, 2001.

BAPTISTA, Bárbara Gomes Lupetti. Paradoxos e Ambiguidades da Imparcialidade Judicial: entre. Porto Alegre: Sergio Antonio fabris, 2013.

BARBOSA, Rui. Oração aos moços. Edição popular anotada por Adriano da Gama Kury. - 5. ed. - Rio de Janeiro: Fundação Casa de Rui Barbosa, 1997.

BERNARDINA, Milena Dalla. A Via Crucis do Cidadão Capixaba: herança e propriedade. Autografia: Rio de Janeiro, 2019. 
BRITO, Wagner. A celeridade Processual: uma pesquisa empírica nos cartórios judiciais da capital do Rio de Janeiro / Wagner brito. - 1. ed. - Rio de Janeiro: Autografia, 2017.

CARDOSO DE OLIVEIRA, Luís Roberto. Direito Legal e Insulto Moral: dilemas da Cidadania no Brasil, Quebec e EUA. 2 ${ }^{\text {a }}$. Ed. Rio de Janeiro, Garamond, 2011.

CORRÊA, Cláudia Franco. Controvérsias entre o 'Direito de Moradia' em favelas e o Direito de Propriedade Imobiliária na cidade do Rio de Janeiro: 'O Direito de Laje' em questão. Rio de Janeiro: Topbooks, 2012.

DAMATTA, Roberto. Carnavais, Malandros e Heróis. Rio de Janeiro: Zahar, 1979.

DUARTE, Fernanda; IORIO FILHO, Rafael Mario. A Lógica Do Contraditório: ainda somos medievais. In: CONPEDI/UFS; Gustavo Silveira Siqueira; Antonio Carlos Wolkmer; Zélia Luiza Pierdoná. (Org.). História do direito [Recurso eletrônico on-line]. 1ed.Florianópolis: CONPEDI, 2015, p. 1-23.

. Judicial Deference In Brazil And In The United States Of America: A comparative overview. Juris Poiesis, v. 22, p. 295-299, 2019.

EILBAUM, Lucía. "O Bairro Fala": Conflitos, moralidades e justiça no conurbano bonaerense. São Paulo: ANPOCS/HUCITEC, 2012.

FERREIRA, Marco Aurélio Gonçalves. O Devido Processo Legal: um estudo comparado. 1. ed. Rio de Janeiro: Lumen Juris, 2004.

FIGUEIRA, Luiz Eduardo. O Ritual Judiciário do Tribunal do Júri: O Caso do Ônibus 174. Porto Alegre: Sergio Antonio Fabris, 2008.

FILGUEIRAS, Márcio de Paula. As categorias interesse público e public interest no Brasil e nos EUA. In: Duarte, F.; Iorio Filho, R. M.; Lima, R.K (orgs). O Judiciário nos Estados Unidos e no Brasil: análises críticas e pesquisas comparadas. Curitiba: Editora CRV, 2015. p. 93-122.

FILPO, Klever Paulo Leal. Mediação Judicial Discursos e Práticas. 1. ed. Rio de Janeiro: Mauad Editora Ltda, 2016.

GARAPON, Antoine; PAPADOPOULOS, Ioannis. Julgar nos Estados Unidos e na França. Rio de Janeiro: Lumen Juris, 2008.

GARAU, Marilha Gabriela Reverendo. Tradição inquisitorial em perspectiva comparada: práticas judiciais no ritual das audiências criminais no Brasil e juicios orales na Espanha. In: Michel Lobo Toledo Lima; Roberto Kant de Lima (Org.). Entre Normas e Práticas: os campos do Direito e da Segurança Pública em Perspectiva Empírica. 1ed.Rio de Janeiro: Autografia, 2020, v. 1, p. 172-199.

GEERTZ, Clifford. O Saber Local: novos ensaios em antropologia interpretativa. Petrópolis: Vozes, 2002. 
GERALDO, Pedro Heitor Barros; FONTAINHA, Fernando de Castro. Por uma Sociologia Empírica do Direito. In: FONTAINHA, Fernando de Castro; GERALDO, Pedro Heitor Barros. (Org.). Sociologia Empírica do Direito. 1ed.Lisboa: Juruá, 2016, v. 1, p. 9-20.

GERALDO, Pedro Heitor Barros. Políticas Públicas Judiciárias: Uma abordagem comparativa entre a organização social da Justiça no Brasil e na França. Revista Juris Poiesis, v. 22, p. 309$328,2019$.

LIMA, Michel Lobo Toledo; LIMA, Roberto Kant (Org.). Entre normas e práticas: os campos do Direito e da Segurança Pública em perspectiva empírica. 1. ed. Rio de Janeiro: Autografia, 2020. v. 34.

LIMA, Michel Lobo Toledo. A Formação do Conhecimento no Campo do Direito e das Ciências Sociais: Questões Teórico-Metodológicas. CONFLUÊNCIAS, v. 1, p. 41-63, 2015.

LIMA, Roberto Kant de. Pesquisa Empírica no Direito e na Segurança Pública: Doutrina, Teoria e Práticas. In: Entre normas e práticas: os campos do Direito e da Segurança Pública em perspectiva empírica. 1. ed. Rio de Janeiro: Autografia, 2020. v. 34. P. 9-19.

O Projeto De Lei Anticrime de 2019 e as "Soluções Negociadas": Uma Análise Comparativa Por Contrastes Com o Modelo Norte-Americano do Plea Bargain. In: Roberto Kant de Lima; Maria Stella Faria de Amorim; Michel Lobo Toledo Lima (Org.). Administração de conflitos e cidadania: problemas e perspectivas IV. 1ed.Rio de Janeiro: Autografia, 2020, v. 33, p. 123-163.

- Próximo da Justiça, distante do Direito: administração de conflitos e demanda de direitos no Juizado Especial Criminal. Autografia: Rio de Janeiro, 2017.

LIMA, Roberto Kant de. A polícia da cidade do Rio de Janeiro: seus dilemas e paradoxos. 3ed. Rio de Janeiro: Amazon, 2019.

Sensibilidades jurídicas, saber e poder: bases culturais de alguns aspectos do direito brasileiro em uma perspectiva comparada. ANUÁRIO ANTROPOLÓGICO, v. 2, p. 25-51, 2010.

MENDES, Regina Lúcia Teixeira. Do princípio do Livre Convencimento Motivado. Legislação, Doutrina e interpretação de Juízes brasileiros. Rio de Janeiro: Lumen Juris, 2012.

MOUZINHO, Gláucia Maria Pontes. 2019. Sobre culpados e inocentes: o processo de criminação e incriminação pelo Ministério Público Federal brasileiro. Rio de Janeiro: Autografia, 2019.

NUÑEZ, Izabel Saenger. Aqui nós somos uma família: brigas e acordos no Tribunal do Júri. 1 . ed. Rio de Janeiro: Autografia, 2020.

PAES, Vívian Ferreira. Crimes, Procedimentos e Números: Estudo Sociológico Sobre a Gestão dos Crimes na França e no Brasil. Rio de Janeiro: Garamond, 2013. 
POLICARPO, Frederico. O consumo de drogas e seus controles: uma perspectiva comparada entre as cidades do Rio de Janeiro, Brasil, e de San Francisco, EUA. 1. ed. Rio de Janeiro: Consequência Editora, 2016.

. Os usuários de drogas na justiça: uma etnografia do Programa Justiça Terapêutica da Vara de Execuções Penais do Rio de Janeiro. 1. ed. Rio de Janeiro: Editora Autografia, 2020.

RIBEIRO, Carlos Antônio Costa. Estudo e Análise da Justiça no Rio de Janeiro (1900-1930). Rio de Janeiro: Editora da Universidade Federal do Rio Janeiro, 1995.

SETA, Cristina Gomes Campos de. Consenso nas Decisões do Supremo Tribunal Federal: um estudo empírico sobre a construção da verdade jurídica. Rio de Janeiro: Lumen Juris, 2015.

SIMIÃO, Daniel. Sensibilidades Jurídicas e Respeito às Diferenças: cultura, controle e negociação de sentidos em páticas judiciais no Brasil e em Timor-Leste. Anuário Antropológico, v. 39, p. 237-260, 2014.

SCHRITZMEYER, Ana Lúcia Pastore. Jury trials in Brazil and in France: a comparative study on the Anthropology of Law. In: 18th IUAES World Congress, 2018, Florianópolis. Conference Proceedings - 18th IUAES World Congress. Florianópolis: Tribo da Ilha, 2018. v. 1(A-D). p. 325-335.

SOARES, Gláucio Ary Dillon. O Calcanhar Metodológico da Ciência Política no Brasil. Sociologia, Problemas e Práticas, n. 48, 2005, p. 27-52.

VARGAS, Joana Domingues. Crimes Sexuais e Sistema de Justiça. São Paulo: IBCCrim, 2000.

VIDAL, Paula Chagas Lessa. Os Donos do Carimbo: Investigação Policial Como Procedimento Escrito. Rio de Janeiro: Lumen Juris, 2013. 